\title{
A-Kinase Anchor Protein 6
}

National Cancer Institute

\section{Source}

National Cancer Institute. A-Kinase Anchor Protein 6. NCI Thesaurus. Code C134592.

A-kinase anchor protein 6 (2319 aa, $\sim 257 \mathrm{kDa}$ ) is encoded by the human AKAP6 gene.

This protein is involved in the positive regulation of protein kinase A-mediated signaling. 